\title{
Hubungan Kadar $\beta$ HCG Praevakuasi, Gambaran Histopatologi, dan Kista Lutein dengan Performa $\beta$ HCG pada Penderita Mola Hidatidosa yang Berkembang Menjadi PTG dan Kembali Normal
}

\author{
Yudi Mulyana Hidayat, Supriadi Gandamihardja, Sofie Rifayani Krisnadi \\ Departemen Obstetri dan Ginekologi Fakultas Kedokteran Universitas Padjadjaran \\ Rumah Sakit Dr. Hasan Sadikin Bandung
}

\begin{abstract}
Abstrak
Insidensi penyakit trofoblas di Indonesia maupun negara berkembang masih cukup tinggi dibandingkan dengan negara maju. Hal yang perlu diwaspadai adalah terjadinya penyakit trofoblast gestasional (PTG) pascaevakuasi mola hidatidosa berkisar 10-20\%. Beberapa variabel klinis telah diteliti sebagai variabel faktor risiko keganasan seperti kadar $\beta$-human chorionic gonadotropin ( $\beta \mathrm{HCG}$ ) praevakuasi, gambaran histopatologi, dan terdapat kista lutein. Tujuan penelitian ini adalah mengetahui hubungan kadar $\beta H C G$ praevakuasi, gambaran histopatologi dan kista lutein dengan performa penurunan $\beta \mathrm{HCG}$ pada penderita mola. Metode penelitian yang digunakan adalah case control study pada penderita mola hidatidosa komplet di Rumah Sakit Dr. Hasan Sadikin Bandung selama periode tahun 2007-2011. Hasil penelitian menunjukkan hubungan bermakna kadar $\beta H C G \geq 100.000 \mathrm{mIU} /$ $\mathrm{mL}$ dengan keganasan pascamola $(\mathrm{p}<0,05)$, terdapat hubungan bermakna gambaran histopatologi proliferasi berlebih dengan keganasan pascamola $(\mathrm{p}<0,05)$, dan terdapat hubungan bermakna kista lutein positif dengan keganasan pascamola $(p<0,05)$. Simpulan penelitian ini adalah variabel kadar $\beta H C G$ praevakuasi $\geq 100.000 \mathrm{mIU} /$ $\mathrm{mL}$, gambaran histopatologi proliferasi berlebih, dan kista lutein positif memiliki korelasi dengan keganasan pascaevakuasi mola. Variabel faktor risiko tersebut dapat digunakan untuk memilahkan penderita mola hidatidosa komplet risiko tinggi atau risiko rendah untuk kejadian keganasan dan variabel faktor risiko keganasan tersebut berpengaruh pada performa penurunan kurva regresi $\beta$ HCG. [MKB. 2014;46(4):247-52]
\end{abstract}

Kata kunci: Gambaran histopatologi, kadar $\beta \mathrm{HCG}$, kista lutein, mola hidatidosa komplit, PTG

\section{Relationship between Pre-Evacuation $\beta$ HCG Level, Histopathologycal View, Lutein Cysts and $\beta$ HCG Performance in Patients with Hydatidiform Mole which Developed into Gestational Trophoblastic Disease (GTD) and Back to Normal}

\begin{abstract}
The incidence of trophoblastic diseases in Indonesia and developing countries is relatively high compared to the developed countries. The incidence of gestational trophoblast tumors (GTT) after the evacuation of a hydatidiform mole ranges from $10 \%$ to $20 \%$. Several clinical variables have been studied as the risk factors for malignancy, including the pre-evacuation level of beta human chorionic gonadotropin $(\beta \mathrm{HCG})$, histopathological appearance, and the presence of lutein cysts. The purpose of this study was to determine the relationship between $\beta H C G$ decline and pre-evacuation $\beta$ HCG levels, histopathological features, and the lutein cysts status in patients with moles. This study was a case control study of patients with complete hydatidiform mole in Dr. Hasan Sadikin General Hospital during the period of 2007-2011. The results revealed that there was a significant correlation between the level of $\beta H C G \geq 100,000 \mathrm{mIU} / \mathrm{mL}$ and post-molar malignancy $(\mathrm{p}<0.05)$. There was also a significant relationship between the histopathologic feature of excessive post-molar cell proliferation and malignancy $(p<0.05)$ and between the presence of lutein cyst and post-molar malignancy $(\mathrm{p}<0.05)$. This study concludes that the pre-evacuation $\beta H C G$ level $\geq 100.000 \mathrm{mIU} / \mathrm{mL}$, excessive proliferation, and the presence of lutein cysts are correlated with malignancy after molar evacuation. These risk factors are useful to differentiate whether a complete hydatidiform mole will become malignant or remain benign. [MKB. 2014;46(4):247-52]
\end{abstract}

Key words: Beta human chorionic gonadotropin levels, histopathologic features, lutein cysts, complete hydatidiform mole, gestational trophoblast tumors

Korespondensi: Yudi Mulyana Hidayat, dr., Sp.OG(K), Departemen Obstetri dan Ginekologi Fakultas Kedokteran Universitas Padjadjaran/Rumah Sakit Dr. Hasan Sadikin Jl. Pasteur No. 38 Bandung, mobile 08122024759, e-mail yudiemha@yahoo.co.id 


\section{Pendahuluan}

Insidensi penyakit trofoblas di Indonesia maupun negara berkembang masih cukup tinggi apabila dibandingkan dengan negara yang maju., ${ }^{1,2}$ World Health Organization (WHO) melaporkan angka kejadian mola hidatidosa berkisar antara 1:1.450 hingga 1:2.000 kehamilan dan angka kejadian koriokarsinoma 1:14.000 sampai dengan 1:40.000 kehamilan,,$\frac{1}{}$ sedangkan di Indonesia kejadian mola 1:51 sampai 141 kehamilan, di Jawa Barat 1:28 sampai 1:105 kehamilan. ${ }^{1-3}$

Hal yang perlu diwaspadai adalah terjadinya keganasan pascaevakuasi mola hidatidosa yang berkisar sebesar 15-20\%. Keganasan pascamola berkembang sangatcepat denganjumlahmortalitas yang cukup tinggi, yaitu sebesar 31-51\%.1-6 Risiko terjadinya keganasan pascaevakuasi mola dan deteksi dini keganasan pascaevakuasi mola belum diketahui dengan jelas. Beberapa variabel demografi, klinis, dan labolatorium telah diteliti sebagai variabel faktor risiko keganasan, seperti usia, paritas, besar uterus, terdapat kista lutein, gambaran histopatologi, dan juga kadar $\beta$-human chorionic gonadotropin ( $\beta \mathrm{HCG}$ ) praevakuasi. Hingga saat ini masih diteliti lebih jauh variabel mana yang besar peranannya di dalam terjadinya keganasan. ${ }^{1-5,8}$

Prognosis penyakit trofoblas ganas (PTG) lebih buruk, biaya pengobatan lebih mahal, dan sulit bila dibandingkan dengan penderita mola yang kembali normal. Oleh karena itu sangatlah penting mengevaluasi penderita mola hidatidosa komplit yang akan berkembang menjadi ganas sedini-dininya, sehingga mampu diberikan terapi profilaksis kemoterapi atau histerektomi terhadap penderita mola hidatidosa komplet dengan risiko tinggi untuk mencegah terjadinya keganasan.

Pada penelitian sebelumnya telah diketahui variabel-variabel faktor risiko keganasan, seperti gambaran histopatologi, besar uterus, terdapat kista lutein, dan kadar $\beta H C G$. Dari beberapa kepustakaan telah diketahui bahwa besar uterus adalah efek sekunder dari proliferasi sel trofoblas (gambaran histopatologi) dan kista lutein adalah efek sekunder dari tingginya $\beta \mathrm{HCG}^{3-5,7-10}$

Penelitian yang dilakukan ini yaitu merupakan upaya untuk dapat mengungkap hubungan kadar $\beta \mathrm{HCG}$ praevakuasi, gambaran histopatologi, dan kista lutein dengan performa penurunan $\beta \mathrm{HCG}$ pada penderita mola sehingga mampu dijadikan sebagai skrining untuk mendeteksi keganasan pascaevakuasi mola hidatidosa.

\section{Metode}

Metode penelitian yang digunakan adalah case control study dan diperoleh 145 penderita mola hidatidosa komplet yang dirawat di RSUP. Dr. Hasan Sadikin Bandung selama periode tahun 2007 hingga 2011, yang memenuhi kriteria inklusi sebanyak 60 kasus penderita mola hidatidosa.

Data seperti variabel kadar $\beta$-human chorionic gonadotropin ( $\beta \mathrm{HCG})$, gambaran histopatologi, dan kista lutein diambil dari data di medical record pasien rawat inap, sedangkan pada data penurunan $\beta \mathrm{HCG}$ diambil dari medical record pasien rawat jalan.

Analisis statistik memakai program statistical product and service solutions (SPSS) dengan uji statistik chi-kuadrat untuk membandingkan gambaran histopatologi, kista lutein, dan kadar $\beta \mathrm{HCG}$ pascaevakuasi pada kelompok penderita mola yang dapat berkembang menjadi penyakit trofoblas gestasional (PTG) dan yang kembali normal, dengan mencari kemaknaan hasil uji yang ditentukan dari nilai $\mathrm{p}<0,05$ dan performa $\beta \mathrm{HCG}$ pascaevakuasi yang dievaluasi dengan membandingkan suatu kurva regresi $\beta \mathrm{HCG}$ dari Moscizuki.

\section{Hasil}

Dari 60 kasus penderita mola hidatidosa komplet

Tabel 1 Hubungan Gambaran Kadar $\beta$ HCG, Histopatologi, dan Kista Lutein pada Penderita MHK yang Berkembang Menjadi PTG dan Kembali Normal

\begin{tabular}{llccc}
\hline & Karakteristik Klinis & PTG & Normal & p \\
\hline \multirow{2}{*}{ Kadar $\beta \mathrm{HCG}$} & $>100.000 \mathrm{mIU} / \mathrm{mL}$ & 21 & 15 & 0,000 \\
& $<100.000 \mathrm{mIU} / \mathrm{mL}$ & 2 & 22 & 0,009 \\
Gambaran PA & Proliferasi berlebih & 14 & 10 & 27 \\
Kista lutein & Proliferasi tidak berlebih & 9 & 3 & 0,024 \\
& Positif & 7 & 34 & \\
\hline
\end{tabular}

Keterangan: PTG: penyakit trofoblas gestasional; MHK: mola hidatidosa komplet; $\beta$ HCG: $\beta$-human chorionic gonadotropin; PA: gambaran histopatologi 


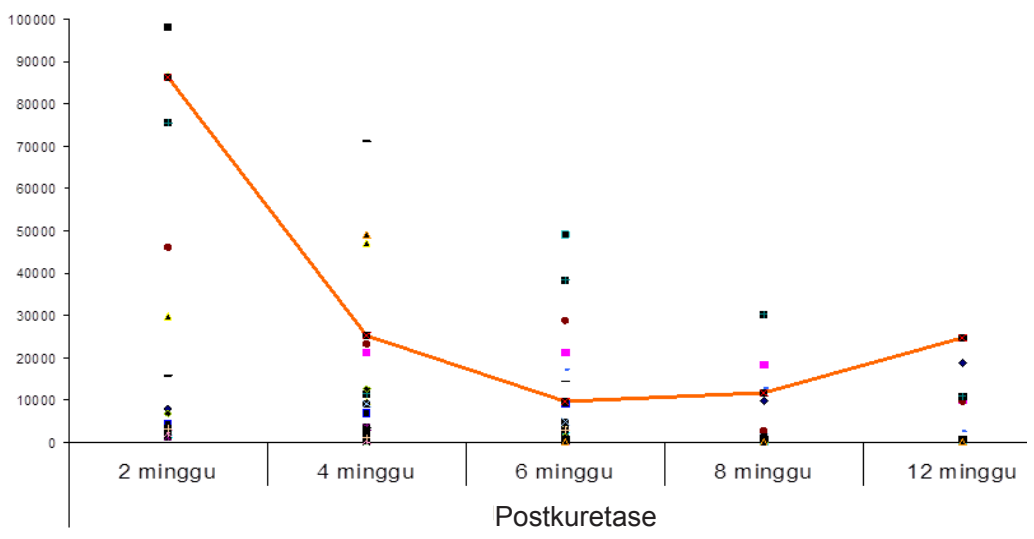

\section{Gambar 1 Performa Penurunan Kadar $\beta H C G$ pada Kasus dengan $\beta H C G \geq \mathbf{1 0 0 . 0 0 0}$ mIU/mL yang Menjadi PTG}

yang memenuhi kriteria inklusi terdapat 23 kasus (38\%) berkembang menjadi PTG dan 37 kasus $(62 \%)$ kembali menjadi normal. Usia ratarata pada kelompok PTG 32 tahun, sedangkan kelompok normal 30 tahun. Dari data gambaran kadar $\beta$ HCG praevakuasi didapatkan hasil pada kelompok PTG kadar $\beta \mathrm{HCG} \geq 100.000 \mathrm{mIU} /$ $\mathrm{mL}$ ada 21 kasus $(91,3 \%)$ dan $\beta \mathrm{HCG}<100.000$ $\mathrm{mIU} / \mathrm{mL}$ ada 2 kasus $(8,7 \%)$, sedangkan pada kelompok normal $\beta \mathrm{HCG} \geq 100.000 \mathrm{mIU} / \mathrm{mL}$ ada 15 kasus $(40,5 \%)$ dan $\beta \mathrm{HCG}<100.000 \mathrm{mIU} / \mathrm{mL}$ ada 22 kasus (59,5\%). Hasil uji statistik kedua kelompok terdapat perbedaan bermakna karena nilai $\mathrm{p}<0,05$.

Dari data hasil gambaran histopatologi pada kelompok PTG terdapat sebanyak 14 kasus $(60,9 \%)$ dengan proliferasi berlebih dan 9 kasus $(39,1 \%)$ proliferasi tidak berlebih, sedangkan pada kelompok normal terdapat 10 kasus (27\%) dengan proliferasi berlebih dan 27 kasus (73\%) proliferasi tidak berlebih. Hasil uji statistik kedua kelompok terdapat perbedaan yang bermakna dengan nilai $\mathrm{p}<0,05$. Dari data kista lutein pada kelompok PTG terdapat 7 kasus $(30,4 \%)$ dengan kista lutein positif dan 16 kasus $(69,6 \%)$ dengan kista lutein negatif, sedangkan pada kelompok normal terdapat 3 kasus $(8,1 \%)$ dengan kista lutein positif dan 34 kasus $(91,9 \%)$ dengan kista lutein negatif. Hasil uji statistik kedua kelompok terdapat perbedaan yang bermakna dengan nilai $\mathrm{p}<0,05$.

Pada Gambar 1 tampak bahwa evaluasi kurva regresi $\beta \mathrm{HCG}$ pada kasus dengan kadar $\beta \mathrm{HCG}$ praevakuasi $\geq 100.000 \mathrm{mIU} / \mathrm{mL}$ distorsi kurva terjadi di minggu ke-8.

Pada Gambar 2 tampak bahwa evaluasi kurva regresi $\beta H C G$ pada kasus dengan kadar $\beta H C G$ praevakuasi $\geq 100.000 \mathrm{mIU} / \mathrm{mL}$ distorsi kurva

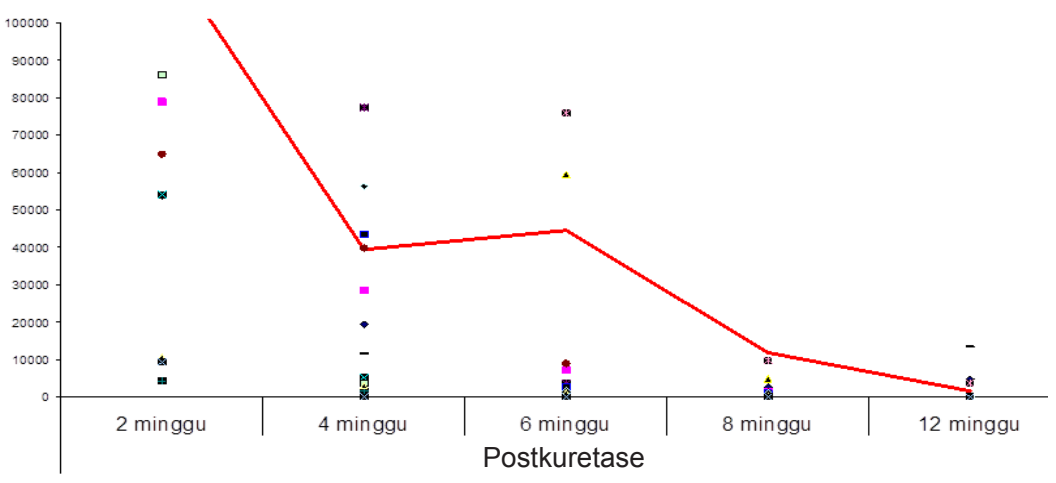

Gambar 2 Performa Penurunan Kadar $\beta H C G$ pada Kasus dengan $\beta H C G \geq 100.000$ mIU/mL yang Kembali Normal 
Yudi M.: Hubungan Kadar $\beta$ HCG Praevakuasi, Gambaran Histopatologi, dan Kista Lutein dengan Performa $\beta H C G$

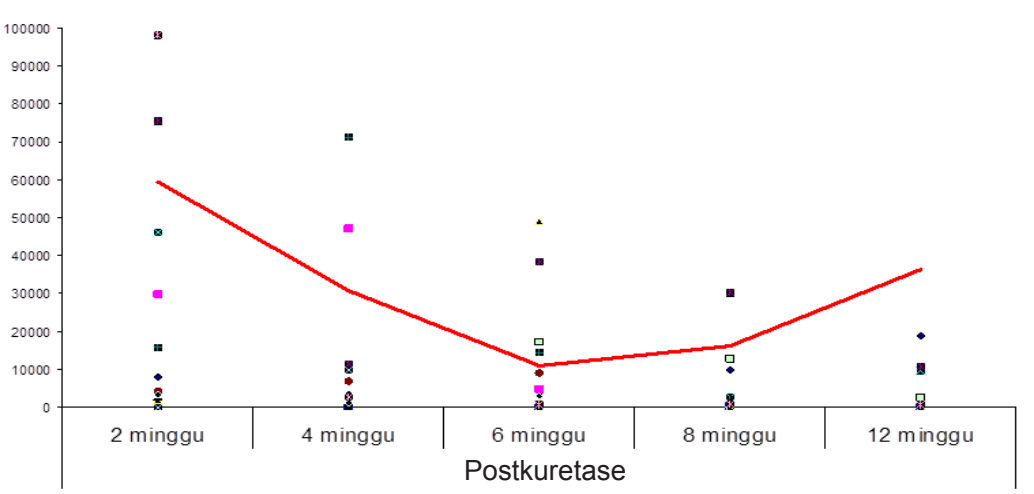

Gambar 3 Performa Penurunan Kadar $\beta$ HCG pada Kasus dengan Gambaran Histopatologi Proliferasi Berlebih yang Menjadi PTG

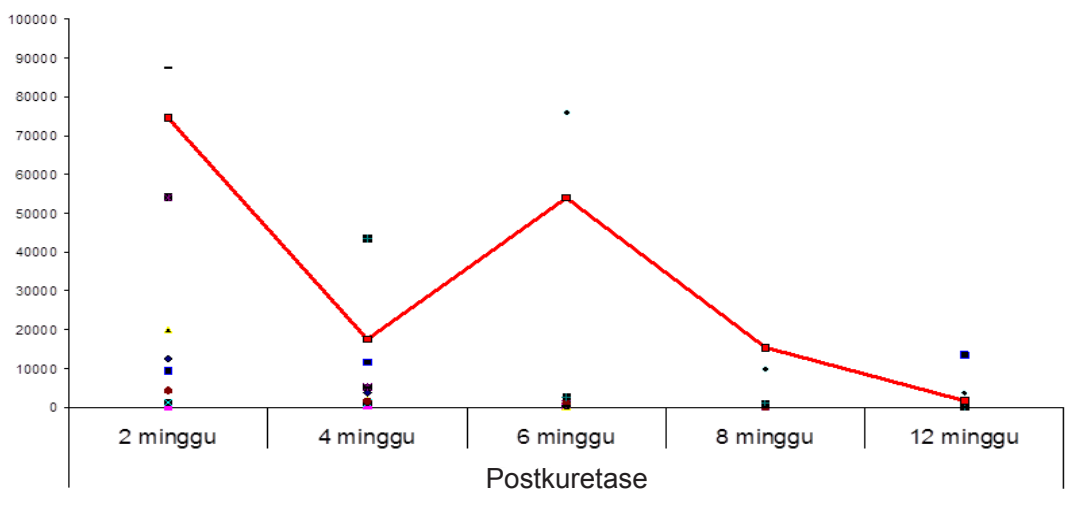

Gambar 4 Performa Penurunan Kadar $\beta$ HCG pada Kasus dengan Gambaran Histopatologi Proliferasi Berlebih yang Menjadi Normal

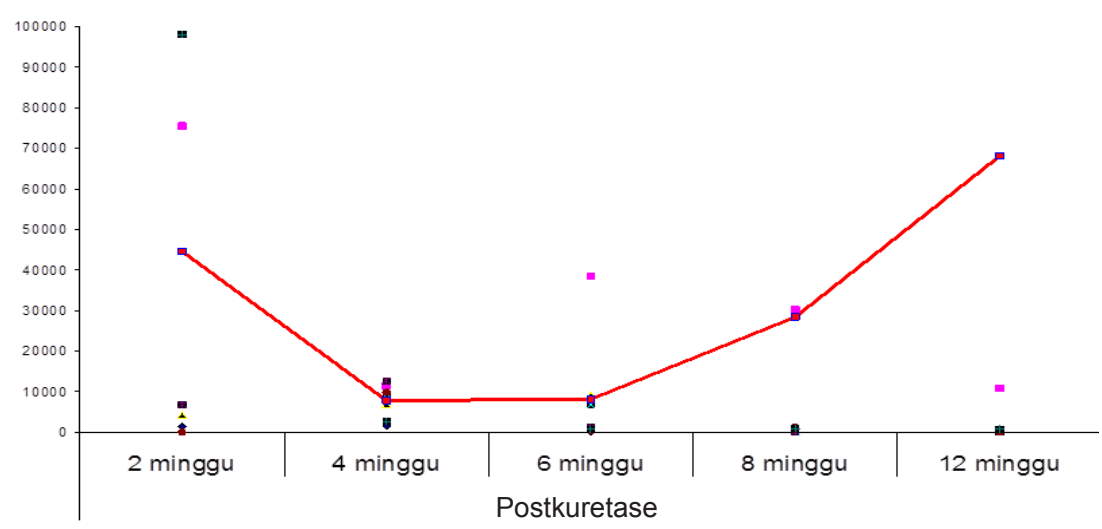

Gambar 5 Performa Penurunan Kadar $\beta$ HCG pada Kasus dengan Kista Lutein Positif yang Menjadi PTG 
terjadi di minggu ke-8 mengalami penurunan pada kelompok yang kembali normal.

Pada Gambar 3 tampak bahwa evaluasi kurva regresi $\beta H C G$ pada kasus dengan gambaran histopatologi yang berlebih terjadi distorsi kurva di minggu ke-8 pada kelompok yang berkembang menjadi PTG.

Pada Gambar 4 tampak bahwa evaluasi kurva regresi $\beta \mathrm{HCG}$ pada kasus dengan gambaran histopatologi berlebih terjadi distorsi kurva di minggu ke- 8 mengalami penurunan.

Pada evaluasi kasus dengan kista lutein positif tampak distorsi kurva $\beta \mathrm{HCG}$ telah terlihat di minggu ke-6 pada kelompok yang berkembang menjadi PTG.

\section{Pembahasan}

Kehamilan mola hidatidosa komplet merupakan suatu kegagalan kehamilan oleh karena gagalnya pemisahan kromosom seks pada saat meiogenesis ovum. Penatalaksanaannya yaitu segera dilakukan evakuasi sebelum timbul komplikasi perdarahan, infeksi, preeklamsi, dan lain-lain. ${ }^{1,6,8-10}$

Pascaevakuasi mola yang perlu diperhatikan adalah terjadinya keganasan (tumor trofoblast gestasional/TTG) Pada penelitian ini, kejadian keganasan tersebut kurang lebih sekitar 38\% lebih tinggi apabila dibandingkan dengan penelitianpenelitian sebelumnya yaitu $20-30 \%{ }^{1,5}$ Keadaan yang sangat penting lagi adalah mengetahui variabel faktor-faktor risiko yang berpengaruh pada terjadinya keganasan pascaevakuasi mola hidatidosa komplet sehingga para klinisi tersebut dapat memilahkan mana yang akan berkembang menjadi ganas (risiko tinggi) atau akan kembali normal (risiko rendah). ${ }^{11,12}$ Dari penelitian ini didapatkan tiga variabel faktor risiko, yakni kadar $\beta \mathrm{HCG}$ praevakuasi $\geq 100.000 \mathrm{mIU} / \mathrm{mL}$, gambaran histopatologi proliferasi berlebih, dan terdapat kista lutein bilateral atau unilateral sebagai faktor risiko yang memengaruhi terjadinya keganasan pascaevakuasi mola dengan uji statistik nilai $\mathrm{p}<0,05$.

Pada gambar performa penurunan $\beta \mathrm{HCG}$ yang dihubungkan dengan variabel faktor risiko tampak dengan jelas kurva regresi yang dibentuk memperlihatkan distorsi kurva bila dibandingkan dengan kurva regresi $\beta \mathrm{HCG}$ pascaevakuasi yang normal dari Moscizuki, ${ }^{11-14}$ yaitu pada kasus dengan kadar $\beta \mathrm{HCG}$ praevakuasinya $\geq 100.000$ $\mathrm{mIU} / \mathrm{mL}$ yang terjadi distorsi pada minggu ke-8 pascaevakuasi, begitu juga pada kasus dengan gambaran histopatologi proliferasi berlebih, Pada kasus dengan kista lutein positif lebih awal terjadi pada minggu ke-6. Pada penelitian ini, penderita mola hidatidosa komplet yang telah berkembang menjadi PTG tetapi tidak mempunyai faktor risiko hanya terdapat $4 \%$ kasus, sebagian besar $96 \%$ mempunyai salah satu atau ketiga faktor risiko tersebut. Artinya, ketiga faktor risiko tersebut mempunyai hubungan yang kuat dengan kejadian keganasan dan berpengaruh pada performa kurva regresi $\beta H C G$ pascaevakuasi.

Simpulan, bahwa variabel faktor risiko kadar $\beta H C G$ praevakuasi $\geq 100.000 \mathrm{mIU} / \mathrm{mL}$, gambaran histopatologi proliferasi sel sangat berlebih, dan terdapat kista lutein mempunyai hubungan yang kuat dengan terjadinya keganasan pascaevakuasi mola. Variabel faktor risiko tersebut mampu digunakan untuk memilah/memprediksi penderita mola yang akan menjadi PTG (risko tinggi) atau kembali normal (risiko rendah). Variabel faktor risiko keganasan yang berpengaruh pada performa penurunan kurva regresi $\beta H C G$, sehingga klinisi harus berhati-hati pada minggu ke- 6 dan minggu ke- 8 terjadinya distorsi kurva $\beta H C G$ pada kasus yang berkembang menjadi PTG.

\section{Daftar Pustaka}

1. Martaadisoebrata D. Protokol pengelolaan penyakit trofoblas gestasional. Edisi ke1. Bandung: Pusat Pengelolaan Penyakit Trofoblas Gestasional; 2005.

2. Khrismawan, Saleh AZ, Sanif R, Theodorus. Efficacy of NETDC (New England Trophoblastic Disease Center) prognostic index score to predict gestational trophoblastic tumor from hydatidiform mole. Med J Indones. 2004;13(1):40-6.

3. Soper JT. Gestasional trophoblastic disease. Am College Obstet Gynecol. 2006;108(1): 176-87.

4. Muminhodzic L, Bogdonavic G, Ljuca D, Babovic A. Epidemiological factors and pathomorphologic characteristics of hydatidiform mole. J Health Sci. 2013;3(2): 129-37.

5. Hernandez E, Huh WK. Gestational trophoblastic neoplasia. Medscape 2013 [diunduh 24 Januari 2014]. Tersedia dari: http://emedicine.medscape.com.

6. Seckl MJ, Sebire MJ, Berkowitz RS. Gestational trophoblastic disease. Lancet. 2010;376:717-29.

7. Andrijono. Penyakit trofoblas gestasional. Jakarta: Divisi Onkologi Departemen Obstetri Ginekologi FKUI Jakarta; 2007.

8. Lurain JR. Gestational trophoblastic disease I: epidemiology, pathology, clinical presentation and diagnosis of gestational trophoblastic disease, and management of hydatidiform mole. Am J Obstet Gynecol. 
Yudi M.: Hubungan Kadar $\beta$ HCG Praevakuasi, Gambaran Histopatologi, dan Kista Lutein dengan Performa $\beta H C G$

2010;203(6):531-9.

9. Deep JP, Sedhai LB, Napit J, Pariyar J. Gestational trophoblastic disease. J Chitwan Medical College. 2013;3(4):4-11.

10. Loh KY, Sivalingam N, Suryani MY. Gestasional trophoblastic disease. Med J Malaysia. 2004;59(5):697-703.

11. Martaadisoebrata D. Buku pedoman pengelolaan penyakit trofoblas gestasional. Edisi ke-1. Bandung: EGC; 2005.

12. Seckl MJ, Sebire NJ, Fisher RA, Golfier F, Massuger L, Sessa C. Gestasional trophoblastic disease: ESMO clinical pratice guidelines for diagnosis, treatment and follow-up. Ann Oncol. 2013;24(Suppl 6):3950.

13. Behtash N, Ghaemmaghami F, Honar H, Riazi K, Nori A, Modares M, dkk. Is normal $\beta H C G$ regression curve helpful in the diagnosis of persistent trophobalstic disease? Int J Gynecol Cancer. 2004;14:980-3.

14. Wolfberg AJ, Berkowitz RS, Goldstein DP, Feltmate C, Lieberman E. Postevacuation hCG levels and risk of gestational trophoblastic neoplasia in woman with complete mola pregnancy. Obstet Gynecol. 2005;106(3):548-52. 